\title{
FIRST ASCERTAINABLE RECORD OF LUDWIGIA PEPLOIDES FROM ROMANIA
}

\author{
Ioana-Minodora SÎRBU ${ }^{1}$, Paulina ANASTASIU ${ }^{2,3}$, Mihaela URZICEANU ${ }^{2,3}$, Tatiana Eugenia SESAN ${ }^{1,4}$ \\ ${ }^{1}$ University of Bucharest, Faculty of Biology, Splaiul Independentei 91-95, RO-050095, Bucharest, Romania \\ ${ }^{2}$ University of Bucharest, Faculty of Biology, Intr. Portocalelor 1-3, RO-060101, Bucharest, Romania \\ ${ }^{3}$ University of Bucharest, „D. Brandza” Botanic Garden, Şos.Cotroceni 32, RO-060114, Bucharest, Romania \\ ${ }^{4}$ Academy of Agricultural Sciences and Forestry „Gheorghe Ionescu-Şişeşti”, Mărăști Blvd. 61,
} RO-011464, Bucharest, Romania

e-mail: ioana.sirbu@drd.unibuc.ro

\begin{abstract}
Ludwigia peploides (Kunth) P.H.Raven - Floating primrose-willow - is native to wetlands of North, Central, and South America, and widely distributed across Africa, Australia, and Asia, and in Europe, where it is listed by EU Regulation no. 2016/1141 as an Invasive Alien Species (IAS) of Union concern. A photograph of the species from Romania taken in the Sâi River Valley (Teleorman County) was published on the Facebook online platform in 2018. This first record, however, lacked further details on the observed specimen or any accompanying herbarium material that would ascertain its correct taxonomic assignation. By carrying out our own field surveys between October and November 2020 we hereby confirm the presence of the species Ludwigia peploides as a new addition to the Romanian alien flora. We identified many specimens occurring along the Sâi River Valley, between Olteanca and Turnu Măgurele localities. We further present preliminary data regarding the distribution, affected habitats, and population extent of Ludwigia peploides in the investigated area. Although several hypotheses can be proposed on the origin of this species in Romania, our current data cannot strongly support any of them. Plant specimens were deposited in the Herbarium collection of the "D. Brandza" Botanic Garden of the University of Bucharest (BUC).
\end{abstract}

Keywords: riverine habitats, macrophytes, Onagraceae, ornamental species, allogenic invasive species, natural protected area, distribution

\section{Introduction}

Europe is currently facing numerous biological invasions, of which aquatic species are highlighted due to their biological and physiological abilities to develop and spread along aquatic habitats [12], making control and eradication measures a real challenge, often with unsatisfactory results. Following the European Union Regulation no. 1143/ 2014 of the European Parliament and of the Council, on the prevention and management of the introduction and spread of invasive alien species[21], the European Commission adopted on the 13th of July 2016 the first list of invasive alien species of Union concern (EU Regulation no. 2016/ 1141 with consolidated forms 2017/ 1263 and 2019/ 1262) [22, 23, 24]. According to the latest consolidated list of species of Union concern, there are 36 plant taxa, of which eight have been reported from Romania so far [1, 2], but only five have a definite presence: Ailanthus altissima (Mill.) Swingle, Asclepias syriaca L., Elodea nuttallii (Planch.) H.St.John, Humulus scandens (Lour.) Merr. and Impatiens glandulifera Royle. In Romania, the most recent syntheses on neophytes estimated the presence of 593 species 
in 2011 [44] and 767 species in 2020 [3], and so far, 130 species were included in the preliminary list of Invasive Alien Species (IAS) [1], from which eight taxa were noted to affect or threaten aquatic habitats (i.e., Azolla filiculoides Lam., Cabomba caroliniana A.Gray, Elodea canadensis Michx., E. nuttallii (Planch.) H.St John, Lemna minuta Kunth., Myriophyllum aquaticum (Vell.) Verdc., Nelumbo nucifera Gaertn., and Vallisneria spiralis L.).

There are about 82 species in 23 sections of Ludwigia (Onagraceae) known worldwide [50], only one of which belongs to the native flora of Europe, namely Ludwigia palustris (L.) Elliot [6, 43]. Ludwigia peploides (Kunth) P.H.Raven (known as Berro de clavo, California water primrose, Floating primrose-willow, Creeping water primrose or Jussie d'orx) is a hydrophyte native to South and Central America and also the Southern part of North America (including Mexico) $[15,4,29]$. However, several sources report the species as being native also to Australia, Northern America, and New Zealand [16,17, 5, 27, invasive.org], although the species has more likely been introduced in these regions [15] as well as in other parts of the world in Africa, Asia and Australia [15, 17, 18, 29, 15, 14, 27]. Ludwigia peploides belongs to sect. Oligospermum with four known subspecies: L. peploides subsp. glabrescens (Kuntze) Raven, L. peploides subsp. stipulacea (Ohwi) Raven, L. peploides subsp. montevidensis (Spreng.) Raven and L. peploides (Kunth) P.H.Raven subsp. peploides, the last two being reported from Europe [15, 27].

The species was presumably first introduced to Europe in the early $19^{\text {th }}$ century on the river Lez in Montpellier, France $[10,11]$ as an ornamental aquatic plant $[25,17,15]$, and has since spread continuously across the continent [17]. Information on the distribution and the invasiveness status of $L$. peploides across Europe is not updated in all open access plant databases that include IAS. Currently, the species has been reported from several European states [Belgium, Croatia, France (including Corsica), Greece, Germany, Italy, Netherlands, Portugal, Spain, Switzerland, United Kingdom] and Turkey as being introduced and spread into the wild [15, 17, 18, 29, 5, 14, 27] (Fig. 1), and is considered invasive in France [15, 5].

Considered as one of the 200 most aggressive plant species in the world [10] and one of the 10 most harmful non-native aquatic species in Europe [22, 39], L. peploides is a plant that possesses some biological and ecological traits that make it highly adaptive and thus a very successful invader. Among them, high ecological tolerance, efficient and competitive life strategies (e.g. overwintering strategy, such as the production of a large number of hardy seeds and persistent submerged vegetative organs), rapid growth rate (e.g., an established population has the ability to double in extent in three to four weeks), or allelopathy are most noticeable [37, 10, 13, 41, 17, 18, $25,5]$. In the introduced areas the species generates severe negative effects, physically and chemically affecting ecosystems and landscapes, interfering in flood control and drainage systems by clogging watercourses, with various impacts caused on local biodiversity, navigation, hunting, fishing, tourism, etc. $[15,16,42,46,25,5,14]$. Furthermore, it was observed that the allelopathic activity of Ludwigia spp. throughout the year can lead to crashes of dissolved oxygen, the accumulation of sulphide and phosphate in the water column, causing dystrophic crises that eventually lead to toxification of ecosystems $[9,11]$. In France, it was recorded that approximately 12 Natura 2000 habitat types (including three wetland habitats) have been affected and are under threat by Ludwigia spp. [15]. 


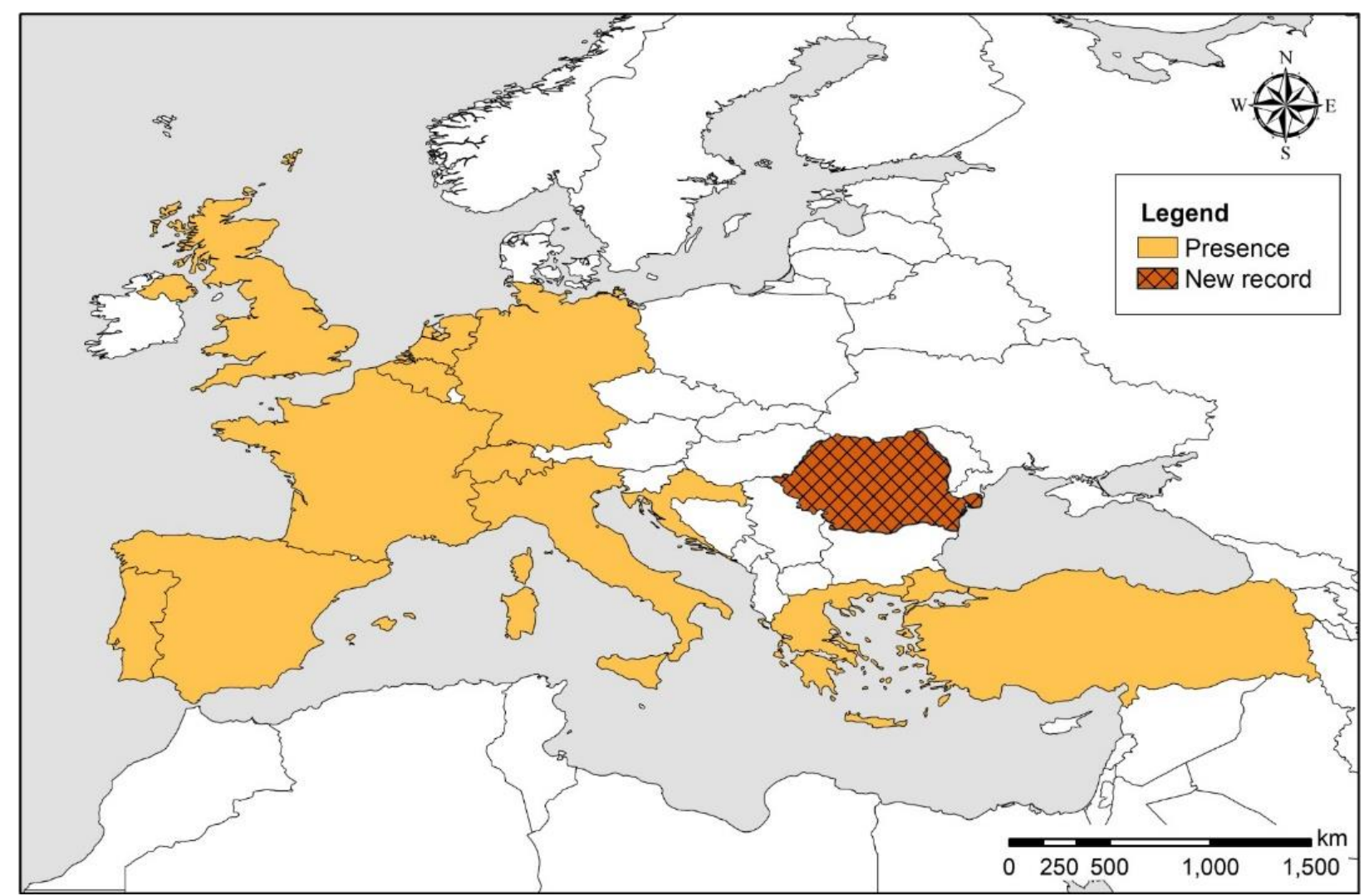

Fig. 1: Distribution of Ludwigia peploides in Europe, including the newly reported presence from Romania

Concerns about the occurrence of this taxon in the natural wetland habitats of Romania date back to 2018, when an online post by Chiriac Sabin (https://www.facebook.com/photo.php?fbid=1996645433979806\&set=gm.615221378847544\&t ype $=3 \&$ theater) drew attention to a plant species unknown to the country's alien flora. At that time, the only data available were a photograph of the species and an indication of the place of observation, namely Sâi River Valley, Teleorman County (Fig. 2). The question of the recorded specimen's identity remained unanswered and this has motivated us to carry on our own field study to clearly establish the taxonomic identity, presence and extent of its distribution in the area of its first report.

We hereby report for the first time the occurrence of L. peploides in Romania, on the Sâi River (Teleorman County, Southern Romania). In addition, we provide information on the extent of its distribution in the investigated area and we evaluate the current and future potential impact on the natural aquatic habitats where it was recorded, and the invasiveness potential of this IAS.

\section{Material and Methods}

\section{Study area}

In order to confirm the presence of L. peploides in Romania, we carried out several field surveys between October and November 2020, within the framework of the project "Adequate management of invasive species in Romania, in accordance with EU Regulation 1143/ 2014 on the prevention and management of the introduction and spread of invasive alien species", SMIS 2014+:120008 (2018-2022). Although we presumed that the taxon will be present along the Sâi River, we extended our survey to Călmăţui River valley (Fig. 2), taking into consideration the fast establishment and invasiveness character of the species in the areas it occupies $[15,25]$. We have 
chosen nine observation points (Table 1) by consulting the satellite imagery of the region, considering the degree of accessibility of both watercourses, respectively the areas of intersection of the two rivers with the inhabited zones. The first seven observation points (S1-S7) were chosen along the watercourse of the Sâi River, starting from the south (the confluence with the Danube) and continuing upstream to the north, corresponding to the territorial administrative units of the localities Turnu Măgurele, Liţa, Olteanca, Pleaşov, Saelele, and Plopii Slăviteşti (Fig. 2), while two additional points (S8 and S9) were selected along the Călmăţui River, located approximately $17 \mathrm{~km}$ to the east of the Sâi River, corresponding to Florica and Putineiu localities (Fig. 2).

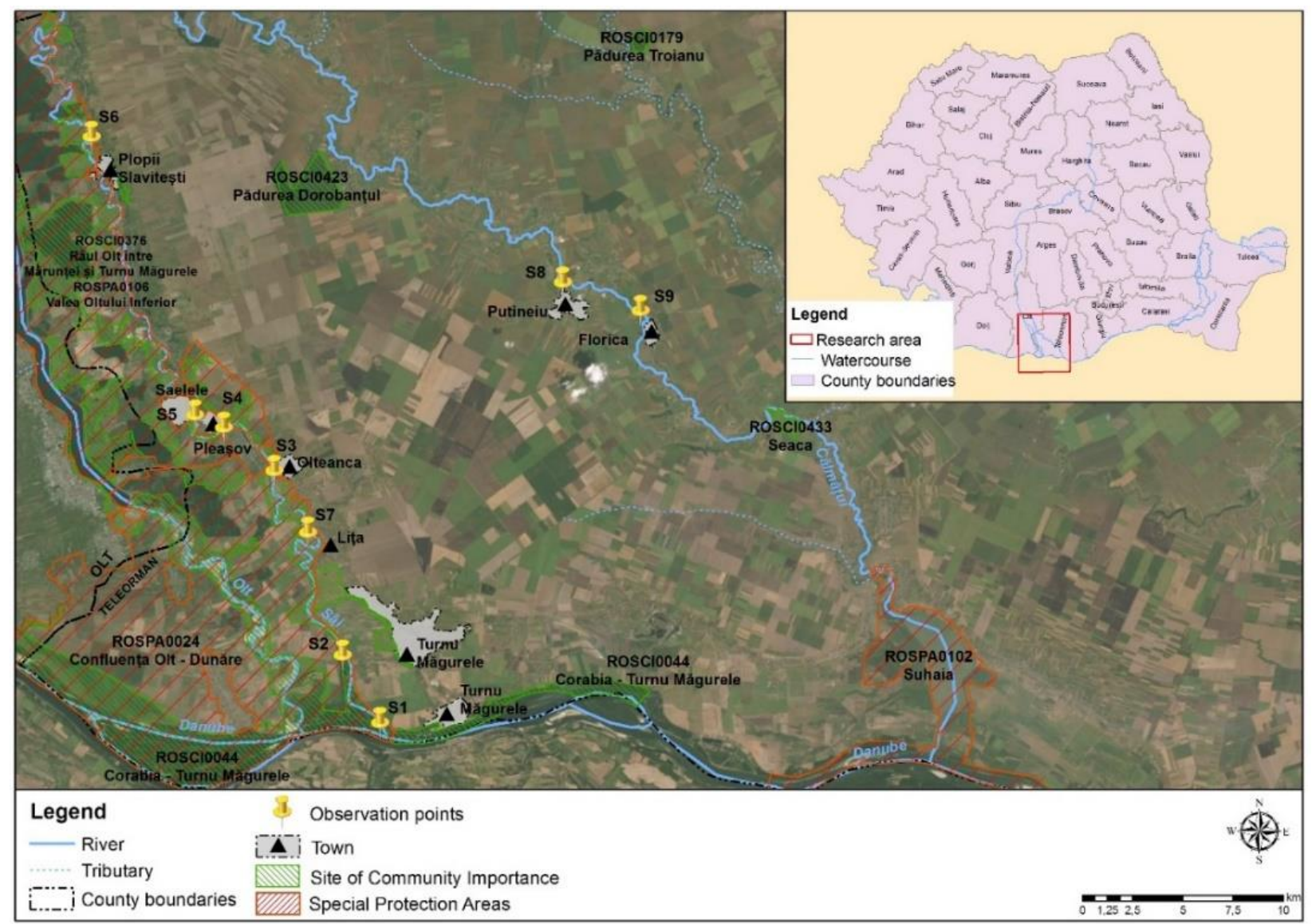

Fig. 2: Spatial distribution of observation points (S1-S9) along the rivers Sâi and Călmățui (Teleorman County) and the Natura 2000 sites they cross

The Sâi River, a left tributary of the Danube, with a length of $85 \mathrm{~km}$ and located east of the Olt River, on the administrative territories of Teleorman and Olt counties, crosses four Natura 2000 sites, namely ROSCI0376 Râul Olt între Mărunţei şi Turnu Măgurele, ROSPA0106 Valea Oltului Inferior, ROSPA0024 Confluenţa Olt-Dunăre and ROSCI0044 Corabia-Turnu Măgurele (Fig. 2). The Călmăţui River, also a tributary of the Danube, with a length of $139 \mathrm{~km}$, develops over the Olt and Teleorman counties, and crosses three Natura 2000 sites, namely ROSCI0423 Pădurea Dorobanţu, ROSCI0433 Seaca and ROSPA0102 Suhaia (Fig. 2).

\section{Data collection and analysis}

We recorded for each observation point where the species was identified the geographical coordinates (WGS84 Coordinate System) (Table 1) using the multi-functional Locus Map 
[www.locusmap.app], a GPS-based mapping application installed on a smartphone device. The distribution maps were elaborated using ArcGIS for Desktop software version 10.4 [20]. In addition, for all nine points, we recorded the accompanying species list. The proper taxonomic assignation of L. peploides was established in accordance with the Global Biodiversity Information Facility [27], while the terminology on the invasiveness status of the species corresponds to the classification rules recommended by Richardson et al. [38] and Pyšek et al. [35]. The collected plant material was deposited in the Herbarium collection of the "D. Brandza" Botanic Garden, University of Bucharest (BUC) (Fig. 3 - BUC 408975 and BUC 408976).

Table 1: Observation points established during the survey for Ludwigia peploides

\begin{tabular}{c|c|c|c|c}
\hline $\begin{array}{c}\text { Observation } \\
\text { point }\end{array}$ & \multicolumn{2}{|c|}{ Geographical coordinates } & Toponym & $\begin{array}{c}\text { Presence/ Absence } \\
\text { of the species }\end{array}$ \\
\cline { 2 - 5 } & 24.85022694 & 43.71494111 & $\begin{array}{c}\text { Sâi River, near Turnu } \\
\text { Măgurele locality }\end{array}$ & A \\
\hline S1 & 24.82706111 & 43.74515 & $\begin{array}{c}\text { Sâi River, near Turnu } \\
\text { Măgurele locality }\end{array}$ & P \\
\hline S3 & 24.78459 & 43.82785611 & $\begin{array}{c}\text { Sâi River, near Olteanca } \\
\text { locality }\end{array}$ & P \\
\hline S4 & 24.75326194 & 43.84711889 & $\begin{array}{c}\text { Sâi River, near Pleaşov } \\
\text { locality }\end{array}$ & A \\
\hline S5 & 24.735415 & 43.85263889 & $\begin{array}{c}\text { Sâi River, near Saelele } \\
\text { locality }\end{array}$ & A \\
\hline S6 & 24.67085389 & 43.97734611 & $\begin{array}{c}\text { Sâi River, near Plopii } \\
\text { Slăviteşti locality }\end{array}$ & A \\
\hline S7 & 24.80546694 & 43.80020889 & $\begin{array}{c}\text { Sâi River, near Liţa } \\
\text { locality }\end{array}$ \\
\hline S8 & 24.96294 & 43.91253889 & $\begin{array}{c}\text { Călmăţui River, near } \\
\text { Putineiu locality }\end{array}$ & P \\
\hline S9 & 25.01118111 & 43.89975306 & $\begin{array}{c}\text { Călmăţui River, near } \\
\text { Florica locality }\end{array}$ \\
\hline
\end{tabular}

L. peploides is a perennial herbaceous aquatic species, sediment-rooted, with emergent flower stems and floating leaves. The roots help the species to attach itself to the substrate and absorb nutrients, while the adventitious roots developed at the internodes favour oxygen root absorption and vegetative propagation. The fleshy stems are glabrous or pubescent, with lengths of between 10 and $300 \mathrm{~cm}$. The polymorphic leaves are petiolate, round to oblanceolate or obovate (during anthesis on vertical shoots the leaves are lanceolate), up to $10 \mathrm{~cm}$ long (1-6 x 0.4-3 cm), narrowed below to the petiole of $2-4 \mathrm{~cm}$ long, having an alternate arrangement on the stems. The flowers are pentamerous, develop solitarily in the axils of the leaves and are small, 9(10)(15)16(22) $\mathrm{mm}$ long and 10(20)-(25)30 mm in diameter, bright yellow coloured. Both the sepals, 6(8)-(12)14 mm long and the fruit (5-sided cylindrical capsule, 13-32 $\mathrm{mm}$ long, with five loculi containing numerous seeds) have rare hairs on the surface. The bracteoles, deltoid to ovate, are placed at the base of the ovary (Fig. 5). The entire plant (except the flowers) has a characteristic shiny aspect $[36,15,34,4,14,49]$.

Taxonomic assignation of individuals to species and especially subspecies within the genus Ludwigia poses major problems due to their high morphological intraspecific variation, possibly caused also by a high level of ploidy variation $[51,10]$. Although using the cytogenetic criteria 
remains the ultimate method for distinguishing between closely-related species, morphological characters can be used to some extent for delimiting taxa belonging to the Oligospermum section [5]. For properly assigning the studied individuals to $L$. peploides species, we compared the collected material with the available data of the species with which it is most often confused, namely Ludwigia grandiflora (Michx.) Greuter \& Burdet and Ludwigia hexapetala (Hook. \& Arn.) Zardini, H.Y.Gu \& P.H.Raven [51, 10, 16, 17]. Among the differentiating characters, the habit of the plants, the shape and the arrangement of the leaves on the stem, the number and shape of the floral elements, the shape and size of the fruit, and the presence or absence of bristles are considered as valid criteria. Both $L$. grandiflora and L. hexapetala have stems that display horizontally, however the flower shoots are always erect, the floral elements are larger, and the bracteoles are lanceolate to lanceolate-ovate compared to L. peploides [16, 34, 4].
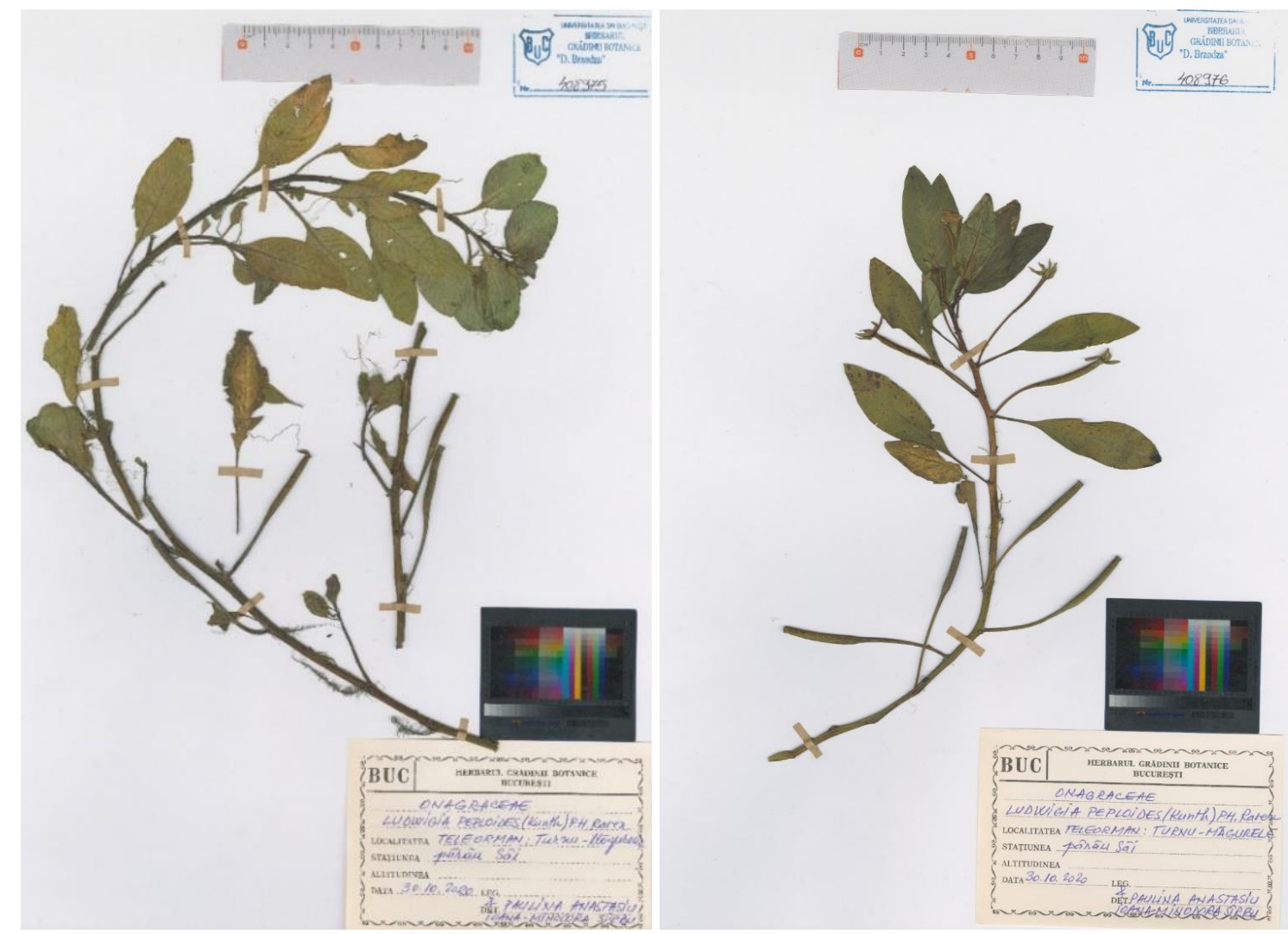

Fig. 3: Plant specimens of Ludwigia peploides collected from the Sâi River (S2 observation point, near Turnu Măgurele locality, see Table 1 for details) deposited in the Herbarium collection of the "D. Brandza" Botanic Garden of the University of Bucharest (BUC)

\section{Results and Discussion}

We recorded the presence of L. peploides in three of the nine investigated points (S2, S3 and, S7) during the field surveys carried out along a $16.8 \mathrm{~km}$ long sector of the Sâi River (Fig. 4, Table 1). The observations on the course of the Călmăţui River (S8, S9) have not revealed the presence of the species so far. The Sâi River seems unaltered by human interventions, having a natural course characterised by slow flowing water along many meanders, a muddy riverbed with variable widths and heights of the banks, and water depths not exceeding 0.5-1(1.5) $\mathrm{m}$. The population formed here by L. peploides appear as specific, highly dense formations. However, at present we cannot say if the distribution was only localized or continuous between the three points 
where the species was recorded.

L. peploides begins its vegetation period in late spring or early summer, reaching anthesis between June/July and October, while in November the aerial parts fall $[10,11,15]$. During the winter, the emerging parts dry out, leaving distinctive brown stems, which by the end of the cold season disappear due to the frost [14]. At the time of observations (October-November), the plants were mostly at the fruiting stage, with partly immature green capsules, while some specimens were still developing new buds, and few others being found in flowering stage (Fig. 5, 7). The late development of this species' individuals differs from that of the native vegetation, which was in the seed dispersal stage or already dried out (Fig. 6, 7). Moreover, when comparing the species native and non-native distribution, the vegetative development of $L$. peploides differs between the two ranges, especially that of the flowering period, which may occur earlier in southern North America (April) in comparison to Europe (June/July) [45, 15, 5]. Even though the species seldomly reaches its full fruiting stage in Romania in existing climate conditions, in the context of climate change sexual reproduction towards the end of the vegetation season and late seeds maturation are expected to become additional surviving and dispersal advantages for L. peploides [28]. However, this phenotipic adaptation might also represent an advantage for $L$. peploides current establishment in new environments especially if the plants manage to reach the seed dispersal phase in years with mild autumns, enhancing seed productivity and thus increasing its competitiveness in relation to local vegetation. Ruaux et al. [41] showed that Ludwigia spp. populations have a high potential of fruit and seed production $\left(10,000-14,000 \mathrm{seeds} / \mathrm{m}^{2}\right)$, which could pose a real threat in regard to the invasive capacity of the species in natural habitats, considering the buoyancy duration (approximately two weeks) of viable fruits and viablility of the seeds that extends up to three months [5].

In all three observation points where L. peploides was found, the native plant communities were composed mainly of Typha angustifolia L. and Phragmites australis (Cav.) Trin. ex Steud. (Fig. 6, 7). Along with the dominant species, we recorded the presence of some other characteristic aquatic taxa, namely Alisma plantago-aquatica L., Berula erecta (Huds.) Coville, Butomus umbellatus L., Ceratophyllum demersum L., Epilobium hirsutum L., Lemna minor L., L. trisulca, Lythrum salicaria L., Mentha pulegium L., Persicaria hydropiper (L.) Spach, Potamogeton lucens L., P. crispus L. and P. fluitans Roth.

In its native area, the species is characteristic for wetlands [40] and transition zones between aquatic and terrestrial habitats [30]. In its non-native area, it invades, among other habitats, stagnant or slow-flowing natural waters, deposit beds of streams formed by pebbles or gravels, wetlands, wet meadows, areas along the edges of ponds and lakes and irrigation channels, and can establish itself even in brackish waters. The species frequently occurs in muddy areas periodically affected by water level fluctuations or on the wetland margins grazed by domestic animals $[52,13,5]$.

Under such habitat conditions, L. peploides forms large, monospecific dominant mats of vegetation and can outcompete both emergent and submerged native aquatic species. However, native tall plant communities may play a beneficial role in partially limiting the expansion of $L$. peploides $[18,14]$.

In each of the three survey points where the species was identified, the population extend for tens to hundreds of meters along the riverbed in the form of mostly continuous open mats distributed on both sides of the water surface, having a variable width starting from the bank area 
to the middle of the river ( $\geq 25 \%$ open water coverage over a length of $100 \mathrm{~m}$ ) that could only be estimated visually (Fig. 6,7). The floating mats often fill the gaps of the reed beds, almost leaving no space for other aquatic plant species in these areas (Fig. 7).

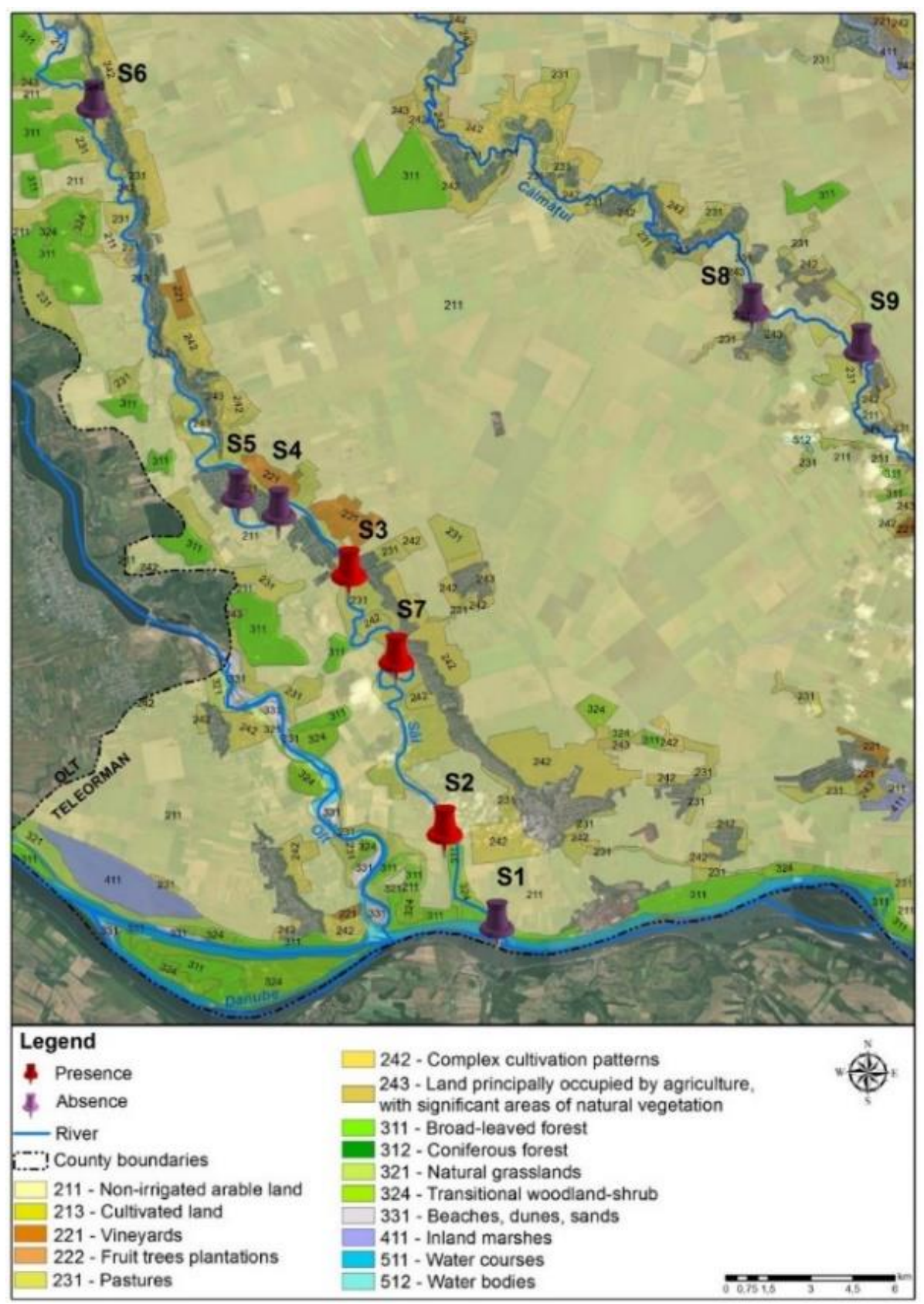

Fig. 4: Location of observation points on the Sâi River (Teleorman County), with indication of those where Ludwigia peploides was identified

The source of introduction of L. peploides into Romania and its main dispersal vectors along the Sâi River are still unclear. We can only speculate on the arrival of the species in the country and assume that it was introduced by humans as an ornamental plant for water basins and aquariums from where it could have escaped or been released into the wild as vegetation debris somewhere upstream of S3 (Olteanca locality). Subsequently, the species could have spread downstream to S7 and S2 (Liţa and Turnu Măgurele localities), mainly through vegetative reproduction. Alternatively, migratory water birds could have played a role in the introduction of 
this species in the country, by carrying ingested seeds and dispersing them into new environments [41, 26, 39]. Additional putative causes for L. peploides dispersal along the Sâi River could be also represented by the movements of wild and domestic animals through water, which can favour the fragmentation of stems and roots (propagules) further transported to new locations by the water current.

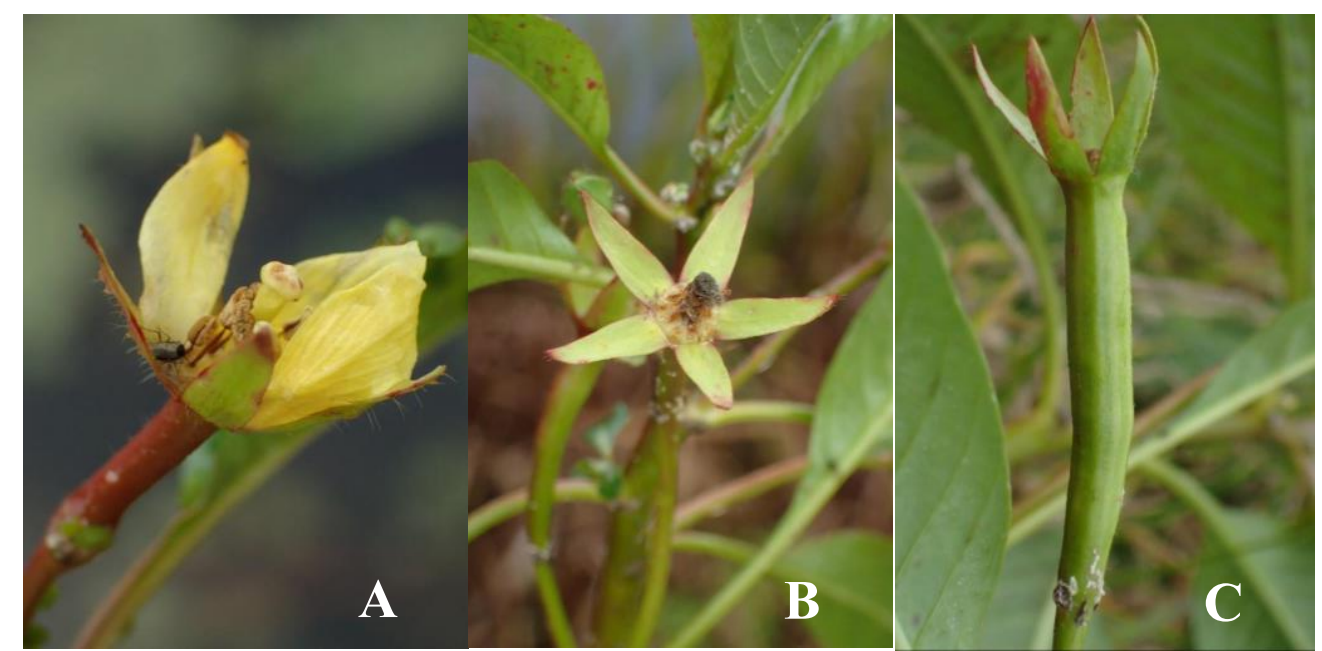

Fig. 5: Details of flower elements (A and B) and fruit (C) of the species Ludwigia peploides (Sâi River, Olteanca locality, Teleorman County, November 2020) (photographs: Paulina Anastasiu)

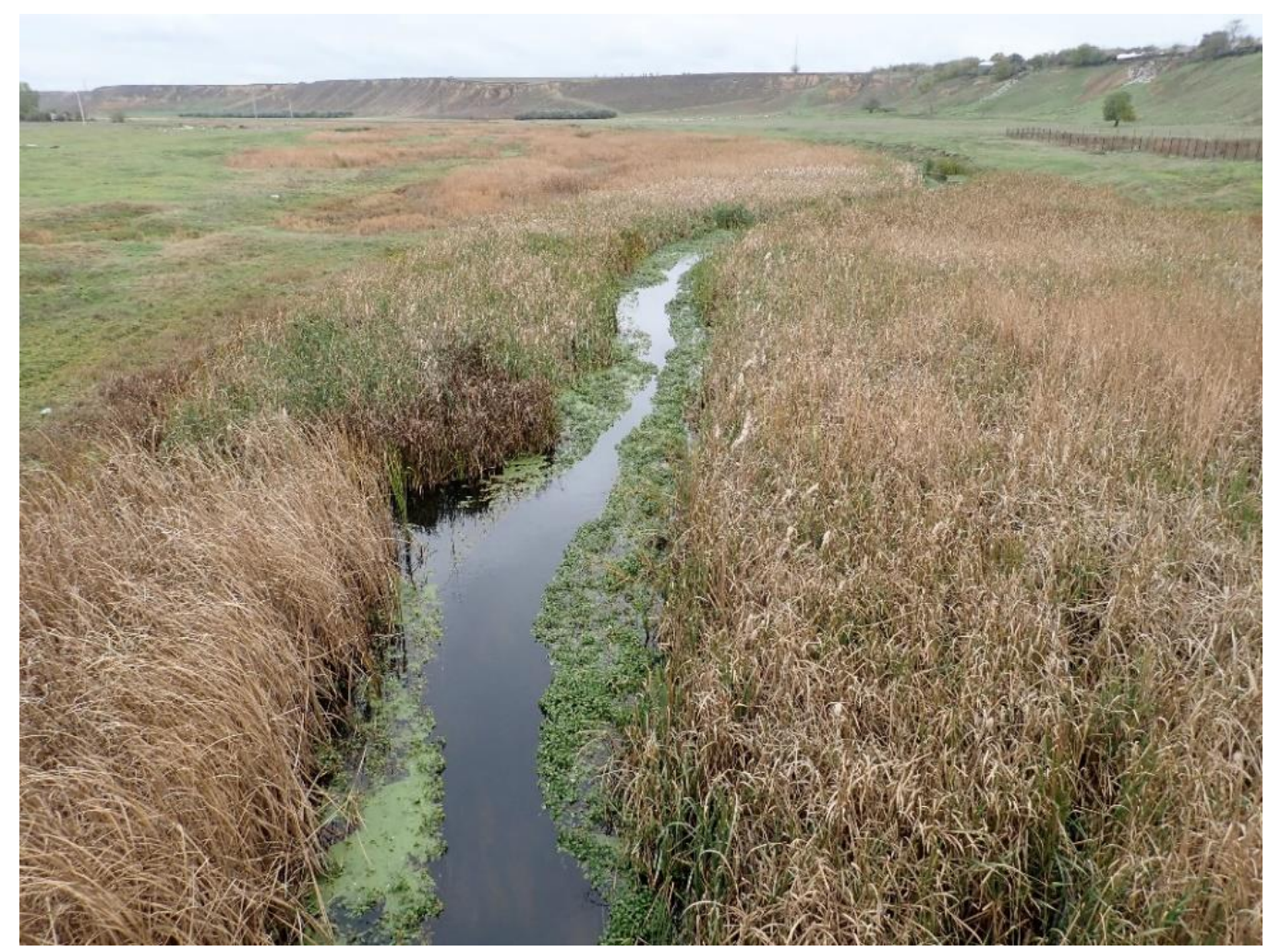

Fig. 6: Spatial configuration and extent of Ludwigia peploides population on the Sâi River (Olteanca, Teleorman County, November 2020) (photograph: Mihaela Urziceanu) 


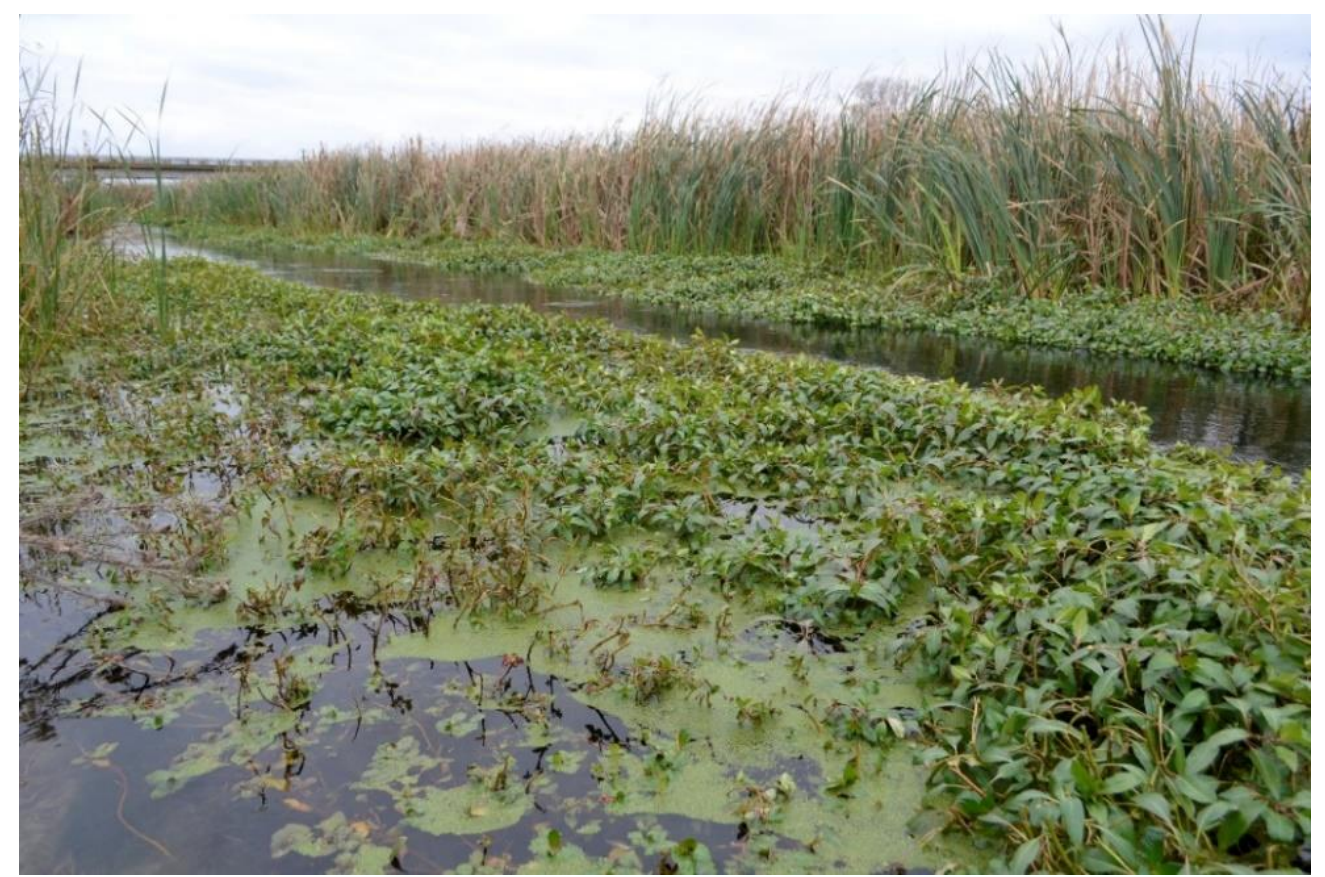

Fig. 7: Habit of Ludwigia peploides, observed on the Sâi River (Olteanca, Teleorman County, November 2020) (photograph: Ioana-Minodora Sîrbu)

The amphibious plant species are a particular group of IAS that possess more advantageous functional adaptations in comparison to native ones. This allows the former to have, for example, higher photosynthetic activity, which leads to faster growth rates and a higher reproductive efficiency, enabling them to form large, compact populations during a short period of time, consequently excluding competitors of the latter category [12, 47]. According to Dandelot et al. [10], Ludwigia species could be considered a 'transformer' species sensu Richardson et al. [38], as they can generate major changes to the environment by i.e. consuming resources like water oxygen and light, shading and occupying the space of native species, ultimately leading to decline or local extinction of native species.

Although we cannot accurately estimate the impact generated by L. peploides on the natural aquatic ecosystem in the area where we discovered it, from the initial observations we can appreciate that the species has a negative impact through the tendency of the individuals to occupy a large proportion of the water surface, forming monospecific communities and thus outcompeting native vegetation. Aquatic habitats are more exposed and vulnerable environments than others to plant invasions, due to features like fast dispersal vectors (e.g. the water current) or changes in the water chemistry that non-native species can facilitate. In the S2 observation point (Sâi River, near Turnu Măgurele locality), during a field survey in 2018, we recorded the presence of two rare aquatic fern species of high conservation value, one included in Natura 2000 Habitats Directive, Annex II, Marsilea quadrifolia L. [8], the other a strictly protected species, Salvinia natans (L.) All. [7]. These two native, EU-protected species were forming large and dense populations at the time of the observation, while during our most recent survey in October 2020 the surface covered by them was reduced due to expansion of $L$. peploides. In fact, of the two species, only $M$. quadrifolia was found, having a lower coverage compared to 2018 and being only marginal to the population of Typha angustifolia.

Previous experience on management actions applied through manual or mechanical methods, undertaken to reduce the impact of aquatic IAS on natural habitats have proven 
insufficient. For an increased efficiency of such interventions, these methods should be carried out in the initial stage of the invasion and throughout the entire affected area, coupled with chemical interventions such as the use of glyphosate, triclopyr and diquat [19]. However, such chemical substances may affect the aquatic ecosystems as a whole and their use may be prohibited in natural areas, protected through national laws. Carried out in the early stages of the infestation, before the plants develop high biomass and compact, extended populations, the eradication measures for invasive species can have positive results [15, 16, 17]. For Ludwigia spp. mechanical control methods (for example, collecting the plants entirely, including seeds or the use of excavators to remove plant material and soil) seem to be most appropriate, but these methods cannot prevent the spread and establishment of the species due to their high regenerative capacity and the ability to quickly form new plants [31] through vegetative fragments. More rigorous and specific measures to limit further introduction of aquatic IAS are the establishment or improvement of specific legislation on the prevention of import and sale and, in specific cases, even banning the use of these species [33, 48]. In Europe, Ludwigia spp. seems to have several natural enemies in the invaded environments (e.g., Altica lythri Aubé, 1843 - Chrysomelidae, Galerucella spp. Chrysomelidae, Procambarus clarkii Girard, 1852 - Cambaridae, Myocastor coypus Molina, 1782 - Echimyidae), and in exceptional conditions, the plant can be eaten by livestock [15, 16, 5].

Knowing the development pattern it follows in the native areas, as well as the behaviour of L. peploides in the areas it invades [16, 17, 5], we consider that the mere presence of the species in the natural water habitats of our country demands urgent intervention through specific management measures adapted to protected aquatic ecosystems. Moreover, as the species is included in the IAS list of Union concern [24], it requires immediate attention and eradication measures in the areas where it occurs. As a member of the European Union, Romania has the obligation to report the presence of the species and to initiate and implement rapid measures for the management and eradication of the existing population and to prevent the further spread of the species.

\section{Conclusions}

We report for the first time the presence of the species Ludwigia peploides in Romania, along the course of the Sâi River (Teleorman County, Southern Romania). In all three locations where the species was identified (S2 - Turnu Măgurele, S7 - Liţa and S3 - Olteanca), the population consists of monospecific formations, developed in the minor riverbed, with an appreciable extent along the watercourse. Apparently, the species expansion significantly impacts the native plant communities, especially protected native species like Marsilea quadrifolia and Salvinia natans. The data obtained so far suggest that the species is naturalized in Romania.

Based on previous experience reported from other European countries about the high negative impact of $L$. peploides on natural habitats, we believe that urgent measures should be undertaken to limit the spread of this taxon, because the risk of it becoming invasive and irrevocably altering natural aquatic ecosystems is exceedingly high. The origin of the species in Romania for the moment can be at most presumed as an unintentional introduction through improper management of aquatic ornamental plants, while its dispersal along the Sâi River may be due to both animal movements and water currents that can displace propagules and carry them to new locations. So far, our data suggest that the vegetative reproduction is the main way of expansion, the current climatic conditions not being optimal for the full maturation of fruits and 
seeds.

We hereby present only preliminary data, while a future assessment of the full extent of the species distribution nationwide and monitoring of the impact on natural habitats in the area where it occurs, is required. Taxonomic studies are also needed to identify the intraspecific affiliation of this newly-reported taxon from Romania.

The species is included in the consolidated list of the 36 invasive alien plant species of Union concern. Considering the data presented in this paper, the number of invasive alien species of Union concern reported from Romania with certain presence amounts now to six taxa.

Acknowledgements: This study was conducted within the project "Adequate management of invasive species in Romania, in accordance with EU Regulation 1143/ 2014 on the prevention and management of the introduction and spread of invasive alien species", SMIS 2014+:120008 (2018-2022). We are grateful to Bogdan-Iuliu Hurdu for his valuable observations and suggestions on the manuscript, and Claudia Tomescu and Alexandra Chelu who helped us design the distribution maps.

\section{REFERENCES}

1. Anastasiu, P. (coord.), Sîrbu, C., Urziceanu, M., 2019, Lista preliminară naţională a speciilor de plante alogene invazive şi potenţial invazive din România în format tabelar. Ministerul Mediului, Apelor şi Pădurilor \& Universitatea din Bucureşti, Bucureşti.

2. Anastasiu, P. (coord.), Sîrbu, C., Urziceanu, M., Camen-Comănescu, P., Oprea, A., Nagodă, E., Gavrilidis, A.A., Miu, I., Memedemin, D., Sîrbu, I., Manta, N., 2019, Ghid de inventariere şi cartare a distribuţiei speciilor de plante alogene invazive şi potenţial invazive din România. Ministerul Mediului, Apelor şi Pădurilor \& Universitatea din Bucureşti, Bucureşti.

3. Anastasiu, P., Sîrbu, C., Negrean, G., Sîrbu, I.M., Urziceanu, M., Gavrilidis, A.A., Oprea, A., 2020, An updated inventory of neophytes reported for Romania, Neobiota $2020-11^{\text {th }}$ International Conference on Biological Invasions, 15-18.09.2020, Vodice, Croatia.

4. Buzjak, S., Sedlar,Z., 2018, Ludwigia peploides (Kunth.) P.H. Raven - Floating Water Primrose, a new species in Croatian flora from the list of invasive alien species of Union concern, Natura Croatica: Periodicum Musei Historiae Naturalis Croatici, 27 (2): 351-356.

5. CABI, 2021, Ludwigia peploides (water primrose). [original text by Alison Mikulyuk, Wisconsin Dept of Natural Resources, Science Operations Center, 2801 Progress Rd, Madison, WI 53716, USA]. In: Invasive Species Compendium. Wallingford, UK: CAB International. www.cabi.org/isc/. Accessed 26 February 2021.

6. Ciocârlan, V., 2009, Flora ilustrată a României: Pteridophyta et Spermatophyta, Ed. Ceres, Bucureşti.

7. Council of Europe, 1979, Convention on the Conservation of European Wildlife and Natural Habitats, Document 104, Strasbourg, France.

8. Council of the European Communities, 1992, Council Directive 92/43/EEC of 21 May 1992 on the conservation of natural habitats and of wild fauna and flora, Official Journal of the European Communities L206: 7-50.

9. Dandelot, S., Matheron, R., Le Petit, J., Verlaque, R., Cazaubon, A., 2005, Temporal variations of physicochemical and microbiological parameters in three freshwater ecosystems (southeastern France) invaded by Ludwigia spp., Comptes Rendus Biologies, 328 (10-11): 991-999.

10. Dandelot, S., Verlaque, R., Dutartre, A., Cazaubon, A., 2005, Ecological, dynamic and taxonomic problems due to Ludwigia (Onagraceae) in France, Hydrobiologia, 551: 131-136.

11. Dandelot, S., Robles, C., Pech, N., Cazaubon, A., Verlaque, R., 2008, Allelopathic potential of two invasive alien Ludwigia spp., Aquatic Botany, 88 (4): 311-316.

12. Delbart, E., Mahy, G., Monty, A., 2013, Effectiveness of techniques used to control the development of five invasive amphibious plant species: Crassula helmsii, Hydrocotyle ranunculoides, Ludwigia grandiflora, Ludwigia peploides and Myriophyllum aquaticum. A review, Biotechnologie, Agronomie, Société et Environnement, 17 (1): 87-102. 
13. Dutartre, A., Haury, J., Dandelot, S., Coudreuse, J., Ruaux, B., Lambert, E., Le Goffe, P, Menozzi, M.J., 2007, Les jussies: caractérisation des relations entre sites, populations et activités humaines. Implications pour la gestion, Programme de recherche INVABIO, rapport final.

14. EASIN. European Alien Species Information Network (europa.eu), 2021, https://easin.jrc.ec.europa.eu/. Accessed 25 March 2021.

15. EPPO, 2011a, Ludwigia grandiflora and L. peploides Onagraceae - Water primroses, EPPO Bulletin, 41 (3): 414-418.

16. EPPO, 2011b, European and Mediterranean Plant Protection Organization, Pest Risk Analysis for: Ludwigia grandiflora, 11-16827.

17. EPPO, 2011c, European and Mediterranean Plant Protection Organization, Pest Risk Analysis for: Ludwigia peploides, 11-16828.

18. EPPO, 2011d, European and Mediterranean Plant Protection Organization, Report of a Pest Risk Analysis for: Ludwigia peploides, 11-17143.

19. EPPO, 2014, PM 9/19(1): Invasive alien aquatic plants, EPPO Bulletin, 44 (3): 457-471.

20. ESRI, 2011, ArcGIS Desktop: Release 10, Environmental Systems Research Institute, Redlands.

21. European Union, 2014, Regulation (EU) No 1143/2014 of the European Parliament and of the Council of 22 October 2014 on the prevention and management of the introduction and spread of invasive alien species, Official Journal of the European Union, L 317: 35-55.

22. European Commission, 2016, Commission Implementing Regulation (EU) 2016/1141 of 13 July 2016 adopting a list of invasive alien species of Union concern pursuant to Regulation (EU) No 1143/2014 of the European Parliament and of the Council, Official Journal of the European Union, L 189: 4-8.

23. European Commission, 2017, Commission Implementing Regulation (EU) 2017/1263 of 12 July 2017 updating the list of invasive alien species of Union concern established by Implementing Regulation (EU) 2016/1141 pursuant to Regulation (EU) No 1143/2014 of the European Parliament and of the Council, Official Journal of the European Union, L 182: 37-39.

24. European Commission, 2019, Commission Implementing Regulation (EU) 2019/1262 of 25 July 2019 amending Implementing Regulation (EU) 2016/1141 to update the list of invasive alien species of Union concern, Official Journal of the European Union, L 199: 1-4.

25. European Commission, 2020, Invasive Alien Species of Union Concern. Version 2020. (p. 18). Publications Office of the European Union: Luxembourg.

26. García-Álvarez, A., van Leeuwen, C.H.A., Luque, C.J., Hussner, A., Vélez-Martín, A., Pérez-Vásquez, A., Green, A.J., Castellanos, E.M., 2015, Internal transport of alien and native plants by geese and ducks: an experimental study, Freshwater Biology, 60 (7): 1316-1329.

27. GBIF Secretariat, 2021, GBIF Backbone Taxonomy. Ludwigia peploides (Kunth) P.H.Raven. In: Checklist dataset. https://doi.org/10.15468/39omei_Accessed 26 February 2021.

28. Gillard, M., Grewell, B.J., Futrell, C.J., Deleu, C., Thiébaut, G., 2017, Germination and seedling growth of water primroses: a cross experiment between two invaded ranges with contrasting climates, Frontiers in Plant Science, 8: 1677.

29. Heidbüchel, P., 2020, Fragment dispersal and its role for the successful spread of native and invasive alien aquatic plants, PhD thesis, Heinrich Heine University, Düsseldorf.

30. Hernández, J., Rangel, J.O., 2009, La vegetación del humedal de Jaboque (Bogotá, DC), Caldasia, 31 (2): 355 379.

31. Hussner, A., 2009, Growth and photosynthesis of four invasive aquatic plant species in Europe, Weed Research, 49 (5): 506-515.

32. Hussner, A., 2010, Growth response and root system development of the invasive Ludwigia grandiflora and Ludwigia peploides to nutrient availability and water level, Fundamental and Applied Limnology, 177 (3): 189196.

33. Hussner, A., 2012, Alien aquatic plant species in European countries, Weed Research, 52 (4): 297-306.

34. Jacono, C., 2017, Identification of common aquatic water-primrose species, Ludwigia, in Florida, Ludwigia ID Guide (ufl.edu), Accessed 20 November 2020.

35. Pyšek, P., Richardson, D.M., Rejmánek, M., Webster, G.L., Williamson, M., Kirschner, J., 2004, Alien plants in checklists and floras: towards better communication between taxonomists and ecologists, Taxon, $\mathbf{5 3}$ (1): 131-143. 
36. Raven, P. H., 1968, Ludwigia peploides (Kunth) P.H. Raven. In: Tutin T.G., Heywood V.H., Burges N.A., Moore D.M., Valentine D.H., Walters S.M., Webb D.A., (eds.), Flora Europaea 2. Cambridge University Press, Cambridge: 308.

37. Rejmánková, E., 1992, Ecology of creeping macrophytes with special reference to Ludwigia peploides (H.B.K.) Raven, Aquatic Botany, 43 (3): 283-299.

38. Richardson, D.M., Pyšek, P., Rejmánek, M., Barbour, M.G., Panetta, F.D, West, C.J., 2000, Naturalization and invasion of alien plants: concepts and definitions, Diversity and distributions, 6 (2): 93-107.

39. Rodríguez-Merino, A., García-Murillo, P., Cirujano, S., Fernández-Zamudio, R., 2018, Predicting the risk of aquatic plant invasions in Europe: How climatic factors and anthropogenic activity influence potential species distributions, Journal for Nature Conservation, 45: 58-71.

40. Rolon, A.S., Lacerda, T., Maltchik, L., Guadagnin, D.L., 2008, Influence of area, habitat and water chemistry on richness and composition of macrophyte assemblages in southern Brazilian wetlands, Journal of Vegetation Science, 19 (2): 221-228.

41. Ruaux, B., Greulich, S., Haury, J., Berton, J.P., 2009, Sexual reproduction of two alien invasive Ludwigia (Onagraceae) on the middle Loire River, France, Aquatic Botany, 90 (2): 143-148.

42. Sarat, E., Mazaubert, E., Dutartre, A., Poulet, N., Soubeyran, Y., 2015, Les espèces exotiques envahissantes dans les milieux aquatiques. Connaissances pratiques et expériences de gestion. 1.

43. Sârbu, I., Ştefan, N., Oprea, A., 2013, Plante vasculare din România: determinator ilustrat de teren, Editura Victor B Victor, Bucureşti.

44. Sîrbu, C., Oprea, A., 2011, Plante adventive în flora României, Editura "Ion Ionescu de la Brad", Iași.

45. Southwest Desert Flora., 2011, Ludwigia peploides, Floating Primrose Willow, Southwest Desert Flora. Accessed 18 May 182021.

46. Thiébaut, G., Tarayre, M., Rodríguez-Pérez, H., 2019, Allelopathic effects of native versus invasive plants on one major invader, Frontiers in plant science, 10: 854.

47. Tóth, V.R., Villa, P., Pinardi, M., Bresciani, M., 2019, Aspects of invasiveness of Ludwigia and Nelumbo in shallow temperate fluvial lakes, Frontiers in plant science, 10: 647.

48. Urziceanu, M., Camen-Comănescu, P., Nagodă, E., Raicu, M., Sîrbu, I.M., Anastasiu, P., 2020, Updated list of non-native ornamental plants in Romania, Contrib. Bot., 55: 59-82.

49. WFO, 2021, Ludwigia peploides (Kunth) P.H. Raven. Published on the Internet. http://www.worldfloraonline.org/taxon/wfo-0000443277, Accessed 26 March 2021.

50. Zardini, E.M., Gu, H., Raven, P.H., 1991, On the separation of two species within the Ludwigia uruguayensis complex (Onagraceae), Systematic Botany, 16 (2): 242-244.

51. Zardini, E.M., Peng, C.I., Hoch, P.C., 1991, Chromosome numbers in Ludwigia sect Oligospermum and sect. Oocarpon (Onagraceae), Taxon, 40 (2): 221-230.

52. Zotos, A., Sarika, M., Lucas, E., Dimopoulos, P., 2006, Ludwigia peploides subsp. montevidensis, a new alien taxon for the flora of Greece and the Balkans, Journal of Biological Research, 5: 71-78.

\section{PRIMA MENȚIONARE CERTĂ A SPECIEI LUDWIGIA PEPLOIDES DIN ROMÂNIA}

\section{(Rezumat)}

Ludwigia peploides (Kunth) P.H. Raven - este originară din zonele umede ale Americii de Nord, Centrală și de Sud și este răspândită pe scară largă în Africa, Australia, Asia şi Europa, în cea din urmă fiind listată prin Regulamentul UE nr. 1143/2014 ca specie alogenă invazivă (IAS) de îngrijorare pentru Uniune. O fotografie a speciei capturată de pe valea râului Sâi (județul Teleorman) a fost publicată din România pe platforma online Facebook în 2018. Cu toate acestea, această primă înregistrare era lipsită de detalii suplimentare cu privire la specimenul observat sau la orice material de herbar însoțitor, prin care să poată fi verificată atribuirea taxonomică corectă. Prin efectuarea propriilor noastre cercetări de teren în perioada octombrie-noiembrie 2020, confirmăm prezența speciei Ludwigia peploides ca o nouă contribuţie la flora alogenă din România. Am identificat numeroase exemplare care apar de-a lungul văii râului Sâi, între localitățile Olteanca și Turnu Măgurele. Prezentăm date preliminare privind distribuţia, habitatele afectate și întinderea populației speciei Ludwigia peploides în zona investigată. Deși pot fi propuse mai 
multe ipoteze cu privire la originea acestei specii în România, datele noastre actuale nu pot susține cu fermitate niciuna dintre acestea. Exemplarele de plante colectate au fost depozitate în colecția Herbarului Grădinii Botanice "D. Brandza" a Universității din Bucureşti (BUC).

Received: 8.09.2021; Accepted: 5.10.2021. 